\title{
Pussy Power: A Contemporaneous View of Indigenous Women and Their Role in Sex Work
}

\author{
Corrinne T. Sullivan (D
}

check for updates

Citation: Sullivan, Corrinne T. 2021. Pussy Power: A Contemporaneous View of Indigenous Women and Their Role in Sex Work. Genealogy 5: 65. https: / / doi.org/10.3390/ genealogy5030065

Received: 15 April 2021

Accepted: 3 July 2021

Published: 14 July 2021

Publisher's Note: MDPI stays neutral with regard to jurisdictional claims in published maps and institutional affiliations.

Copyright: (C) 2021 by the author. Licensee MDPI, Basel, Switzerland. This article is an open access article distributed under the terms and conditions of the Creative Commons Attribution (CC BY) license (https:// creativecommons.org/licenses/by/ $4.0 /)$.
School of Social Sciences, Western Sydney University, Sydney 2751, Australia; corrinne.sullivan@westernsydney.edu.au

\begin{abstract}
Sex work is the trade of sexual services in exchange for money or other goods of value. In the context of Indigenous Australia, sex work often produces narratives of victimisation and oppression reinforcing the patriarchal power and colonial dominance that is rife in Australia over Indigenous women's bodies and behaviours. Drawing from interviews with Indigenous women who are engaged with sex work, this paper challenges these narratives by examining the motivation and meanings that shape Indigenous women's decisions to undertake sex work, offering a compelling counter-narrative that discusses how Indigenous women seek and enact agency, sexuality, and sovereignty through the pussy power of sex work.
\end{abstract}

Keywords: Indigenous; Indigenous women; Aboriginal; sex work; pussy power; sexuality; gender

\section{Introduction}

It is the opening scene; we see the city at night, bright lights, traffic moving, car horns, heavy breathing. Words appear, " ... one of them came in to the water to the side of the boat, we ornamented this naked beauty with strings of beads \& buttons, round her neck, arms and waist" (Bradley 1802). These words are extracted from the diaries of colonist Lieutenant William Bradley as he remarks on the first settlement in the area now known as Sydney, Australia. More heavy breathing, are they sex sounds? The scene of three women making their way through the main strip in Kings Cross, Sydney, appears. We can only see their legs, the sound of their heels striking the footpath, images of shops and nightclubs in the background. Amidst the sounds of the clicking heels, the background noise of other pedestrians, cars, and general sound debris is heard, and then a voiceover, the words of Lieutenant William Bradley are spoken, " ... if ever they deign to come near You, to take a Present, they appear as coy, shy, and timorous, as a Maid on her Wedding Night, (at least as I have been told Maids are) but when they are, as they think out of your Reach, they hollow and chatter to You, Frisk, Flirt, and play a hundred wanton Pranks, equally as significant as the Solicitations of a Covent-Garden Strumpet" (Bradley 1802). Through this soundscape a sense of history is contrasted against the visual of the women walking down an urban city street, thus the present is linked with the past. This is the opening sequence of the 1987 short film Nice Coloured Girls by renowned Aboriginal filmmaker, photographer, and artist Tracey Moffatt (Moffatt 1987).

Moffat's film is remarkably different from other documentaries and realist dramas created by other Indigenous filmmakers, and from ethnographic documentaries produced by non-Indigenous people. In comparison to many films about Indigenous people in Australia, which are often set in the bush or outback portraying Indigenous people in community/kinship environments, Moffat produces the story in an urban landscape and represents the three central Indigenous protagonists as agentic and powerful women. Nice Coloured Girls provides a departure from the dominant representations of Indigenous women, as victims, exploited, and powerless (Sullivan 2018). Instead, the film challenges these representations of Indigenous women throughout history in the country now known as Australia and explores the constructs of Indigenous femininity, sexuality, and power. 
The story portrayed in Moffat's film centres on three Indigenous women who are on the hunt for "Captain". They are wearing high heels, dressed in white clothing, and ready for a great night out, they are in their element. They walk down the street, laughing, happy, and enter a pub together. The women take their seats and start sizing up the men in the establishment, they are looking for a man to pay for their evening, they are looking for "Captain". Indigenous women use the term "Captain" in reference to White men whom they exploit to extract benefits, such as cigarettes, drinks and food, money, transportation, and other goods of value (Moreton-Robinson 2000). Since the invasion and subsequent colonisation of the country now known as Australia, "picking up Captain" has been a method of survival employed by some Indigenous women (Vercoe 1997). The White man, or the 'Captain', is the male victim of Indigenous women's sexual prowess, using their femininity, agency, and pussy power to lure him in, they are not victims. An example of how Indigenous women have captialised on their sexuality and femininity to gain benefits from White men is exposed in Nice Coloured Girls, thus disrupting the racial contempt that has historically defined Indigenous women.

The inclusion of William Bradley's diaries serves two key purposes; firstly, it upholds that Indigenous women have sought the wares of the White man, such as the beads, buttons, and presents, that were given when interactions occurred. Evidently, when Indigenous women covet the items that the White man have, they try to secure them (Sullivan 2018). Secondly, the diaries highlight the view of how this behaviour was understood; there is an emphasis on the naked state. There is also the "frisk", "flirt", "wanton pranks", and the insinuation that the behaviour is that of a "Covent-Garden Strumpet". In other words, someone, usually a woman, who would use their body to secure benefits-today we might use the term "sex worker" rather than "Covent-Garden Strumpet". These examples attest to particular behaviours that Indigenous women employed in order to benefit, to secure the items they sought. Curiously, Bradley's accounts of Indigenous women are cogent with what Indigenous women have long referred to as "picking up Captain". This suggests that Indigenous women were comfortable with their bodies, understood the power of those bodies, and were well acquainted with how to manipulate and exercise that power. This is, of course, precisely what Moffatt wants her viewers to understand. She deftly brings together Indigenous women's ways of knowing, being, and doing, with a colonist narrative that is also demonstrative of this to draw the viewer to the usually ignored and silent topic of Indigenous women's femininity, sexuality, and power.

For Indigenous women, like myself, our femininities, sexualities, and power are rarely recognised, considered, or discussed. Rather than our identities being positioned from our point of view, they are almost wholly represented from the frames of non-Indigenous people. We are largely represented as passive victims of both Indigenous and non-Indigenous male oppression (Bell 2002; Moreton-Robinson 2000), who are unable to support ourselves, or insist upon and defend our identities (Bell 2002; Moreton-Robinson 2000). The historical suppression of Indigenous women's identities is a remarkable and significant intervention of colonio-centric Western social/cultural/political views that have continued to permeate Indigenous community/ies and broader Australian society views (Sullivan 2020b). From the moment of arrival of the colonists, the invasion, and the consequent colonisation of unceded Indigenous lands now known as Australia, the plight of Indigenous women has been catastrophic. The lives, sexual and gendered realities of Indigenous women were radically distorted in most Indigenous communities by dominant patriarchal structures influenced by the advent of colonisation. The projection of colonisation dispossessed Indigenous women of land, agency, security, and constrained the social, cultural, and economic autonomy that existed prior to colonisation (Fredericks 2010).

With the advent of colonisation came the influence of Christianisation and Western moral code over Indigenous belief systems within some communities conflating our own cultural traditions and dogma with these enforced doctrines and rhetoric (Sullivan 2020a). Problems related to sexism and misogyny as well as issues connected to homophobia and transphobia have arisen to become part of a collective Indigenous community reality. 
These problems are forms of oppression that act as pervasive and new forms of colonising practices that have evolved as a result of our colonisation-this is an essential part of the colonial project (O'Sullivan 2019). The alleged necessity for a "civilised" society to develop has appeared to be embraced and the power of Western-based gender roles and behaviours have permeated our communities. The persuasiveness of Indigenous women's identities, femininities, and sexualities that were apparent pre-colonisation and evidenced in the example of Moffatt's film should not continue to be erased. Whilst there is no one way to perform Indigenous "pussy power" — and I maintain that identity, sexuality and femininity, and the expression of those things are individual - there is also opportunity to engage with spaces where these things are expressed and appreciate them both for the individual and collective way that they have been, and could still be, understood.

Drawing from the Black feminist conceptual framework of pussy power to read and discuss the way in which Indigenous women have sought and enacted expressions of femininity, sexuality, and power within the space of sex work, this paper will examine the motivation and meaning that shape Indigenous women's decisions to undertake sex work, offering a compelling counter-narrative that discusses how Indigenous women seek and enact agency, security, and sovereignty through the pussy power of sex work. I will briefly discuss the historical context in which Indigenous women's identities and sexualities have become distorted through ongoing colonial violence using the film Nice Coloured Girls, as outlined above. I will then introduce myself and my position within this paper and how this case study came to be. Finally, I will explore and discuss the way in which Indigenous women have used the space of sex work to explore and shape their own senses of identity, femininity, and sexuality.

\section{Coming to Be}

I begin this section by introducing myself and my theoretical position within this paper. I am a cisgender Indigenous woman from the Wiradjuri Nation located in the Central-West in what is now known as the state of New South Wales, in the country now known as Australia. The case study presented in this article is drawn from my previous doctoral research that explored the lives and experiences of Indigenous sex workers in Australia (Sullivan 2020b). The broader study included participants who were male, female, and transgender. This article will focus on the experiences of the three women who participated in the project. Although one participant identified as transgender and used the pronouns she/her, they never referred to themselves as female or as a woman, rather, described themselves and their gender using the terms "trans", "transgender" and "tranny". Although I would prefer to be inclusive and not discriminate between who and what constitutes a woman, it is my respectful position that as they did not use the term "woman" in their gender description then my inclusion of them in this case study may actually be offensive to that individual. Unfortunately, due to ethical constraints, I am not permitted by my granting institution to follow this up with this participant.

The three participants in this case study identify as female, heterosexual, and Aboriginal or Indigenous Australian, and all work within brothel spaces, although one also engages in street work. Each participant used the terms "Aboriginal" and "Indigenous" interchangeably. In this article, I primarily use the term Indigenous; however, note that no Torres Strait Islanders took part in the study. I use the term Indigenous to highlight that the matters do include and are relevant to all Aboriginal and Torres Strait Islander peoples in the country now known as Australian. Whilst many Indigenous people would prefer to be associated with their country/nation of descent, myself included (Bodkin-Andrews and Carlson 2016), this is avoided in this article in order to protect the anonymity of the participants. Although the participants spoke with pride regarding their country/nation, each recognised the potential danger in doing so, particularly heightened when discussions of sex work, sexuality, and identity can cause social, political, and cultural tension. Those that do undertake sex work risk facing rejection from their communities and families due to the widespread stigma of sex work (Sullivan and Day 2019). 
Each participant was interviewed using a semi-structured questionnaire that focused on their identities, experiences at work, opinions on sex work, and their access to support and services. The same interview guide was used for each participant, although follow-up questions were asked to clarify and probe each of the participant's responses. I did not ask questions related to age, gender, or sexuality, deciding instead to give participants the space to self-report and self-identify. This was done to reinforce the agentic nature of the research and to avoid gratuitous inquiry that is often present in research of nonnormative experience. The three participants within this case study volunteered their identities and/or identifiers within the interviews.

\section{Pussy Power and Sex-Positive Research}

Within academic literature and broader society, perceptions of sex work and therefore sex workers tend to be polarised, oscillating amongst opinions and interpretations that box sex workers within finicky and narrow views. Dominant liberal feminists claim sex work/prostitution is an oppressive tool of the patriarchy, with sex workers portrayed as coerced and/or exploited victims (Jeffreys 2009). This claim, however, that all sex workers are victims of the sex industry demonstrates ideological bigotry and empirical callowness (Maginn and Steinmetz 2015; Weitzer 2012). Countering these views are sex positive feminists who have positioned sex work as part of the labour market, advocating the phrase "sex work is work" (Sanders et al. 2017). Sex-positive perspectives reject the individual discomfort and latent moralising about sexuality and gender ideologies that underlies dominant liberal feminist critiques of sex work. More recently the notion of the sex industry as progressive and queer has emerged (Showden 2012). It has been argued by sex-positive researchers that sex workers subvert heteronormative gender roles as their gendered performativity highlights how gender and sexuality are socially constructed (Jackson 2011; Mavin and Grandy 2013; Read 2013). Feminist advocation for the queering, progression, and diversification of the sex industry undermines hegemonic structures of patriarchy and heteronormativity, away from the exploitation and victimhood discourses of dominant liberal feminists.

The participants in this study illuminate that the interactions they experienced were largely heteronormative and they serviced predominantly male clientele, though there were occasions such as "doubles", where two sex workers service a male client, or where a male/female couple may seek services from them; these examples marginally push at the boundaries of heterosexuality and heteronormativity. What could be concluded within this case study was a reinforcement, rather than a subversion, of gender and sexual expression. However, I argue through the application of pussy power, the Indigenous women in this case study developed and extended the ways in which they expressed and experienced their identities, femininities, and sexualities as a means to challenge preconceived and colonio-centric histories and ideologies of gender and sexuality, and its expressions, that have permeated Indigenous communities and broader Australian society. Although none of the participants used the phrase "pussy power", it was clear through analysis of the interview data that terms such as "pussy", "sex", and "sexy", for example, were regularly linked with words such as "power", "powerful" and "strong". Relating the participants" narratives with "pussy power" theory draws out the connections between Indigenous women and other Black and Indigenous women's experiences of sexuality, femininity, and identity, and therefore contributes to and expands on this literature.

The term "pussy power" is derived from Black feminist scholarship (Hooks 1992), although the concept is fraught given that it can be presumed to be female genitalia, objectifying female sexuality, and wielded unwittingly to other Black women (Roach 2018). The application by Black feminist Hortense Spillers in her essay "Mama's Baby, Papa's Maybe" (Spillers 2000) realises an alternate interpretation and relegates Black sex, gender, and sexualities to colonially ascribed syntaxes. In the African-American context, Spillers contends that in the slave trade femininity and masculinity "adhered to no symbolic integrity" (Spillers 2000), actioned in a way that was a "willful and violent (and 
unimaginable from this distance) severing of the body from its motive will, its active desire" (Roach 2018). Under these conditions, we lost gender difference in the outcome, and the female body and male body became a "territory of cultural and political maneuver", not at all gender-related, but gender-specific (Spillers 2000). Thus the application of pussy power to the Australian context is useful given the histories and contemporalities of pussy power or Indigenous women's identities, femininities, and sexualities being continually infringed upon by state sanctions (Franklin 2014; Huggins 1995, Sullivan 2018), and by colonially informed community-based ideologies (Sullivan 2020a).

\section{Pussy Power and Sex Work}

These theoretical feminist viewpoints that polarise sex work and pussy power as either exploitation or sexual freedom pose a knotty dichotomy. These debates tend not to consider the complexity and nuance of sex workers' experiences, and importantly and pertinent to this case study, rarely include the experiences of Indigenous peoples. My own personal and socio-political perspective of sex work is consistent with the idea that sex work is a lawful (at least in the state of New South Wales where this research is grounded) and recognised form of employment and/or labour. A sex-positive approach to pussy power exposes the sexist and misogynistic shaping of Indigenous women's identities and catapults the practitioners of pussy power to encourage counter-narratives. This strengthsbased position is mobilised to liberate and incorporate the sexual agencies we possess as Indigenous women; however, I also emphasise that this is not definitively the situation for all Indigenous women. Our long histories in this country, in particular our histories of invasion and subsequent colonisation, have meant that many Indigenous peoples have traumatic family histories, many of our children were born as a result of rape, with many sent into sexual servitude on missions and training schools (Franklin 2014; Huggins and Jacobs 2000; Sullivan 2017). Although sex and sexuality, and the expression of those things, have been exploited, used, and abused, as a peoples we also draw on our strength and our defiance against ongoing colonisation, to position us as the purveyors and knowledgeholders of our own bodily landscapes and pussy power. The unshackling of Indigenous women's pussy power means utilising our innate sexual weaponry to emancipate ourselves from colonio-centric Australia. The sexual performativity of Indigenous women in sex work, and on the screen in Nice Coloured Girls, breaks with the ideologies and behaviours that have come to be both expected and demanded of Indigenous women.

I return now to the opening scenes of Nice Coloured Girls, which were detailed earlier. In particular I wish to draw attention to the terms being used, such as "solicitation" and "Covent-Garden Strumpet"; over time these words would also mean prostitute, street walker, and sex worker. Today sex work and sex worker are acceptable terms, and are the terms used by the three participants in this case study. This is how they referred to themselves and their work regardless of whether the transaction occurred in a brothel or street-based environment. Sex work is the trade of sexual services in exchange for money or other goods of value, a concept that is remarkably similar to that of the act of "picking up Captain". Whilst I am not suggesting that sex work is an act performed by all Indigenous women, what I would like to bring to the fore is that some Indigenous women have, over the course of colonisation, used sex work or provided sexual service in order to achieve a benefit. They have cunningly used their sexual power, their pussy power, to exploit White men.

More crucially than my perspective is that of the position of the participants in this study, who all articulated that sex work for them was "work", providing economic rationale and workplace flexibility as the primary reasons for their choice. For example, two of the participants with children appreciated the ability to "work in school hours" (Moira). Another said she sometimes did sex work as a part-time "gig" when she needed extra money and liked that she could go to a known "street corner at any time" (Bianca). However, they all voiced that it was not always easy work, though a choice they would all continue to make. For example, Isabelle noted: 
Some days I just don't want to work, I'm tired, or I have my period, or I just don't feel like dealing with people. Sometimes I don't go when I don't want to, but some days I need to go, because I need the money ... it's no different you know though from when I worked at [deleted], working a straight job is the same. Some days you don't want to go to the office, or the shop, or whatever, but you can't just call your boss and say you don't feel like it, you can't just call your landlord and say 'sorry didn't feel like working this week so I'm not gonna pay rent'. It just doesn't fly like that.

Bianca agreed with Isabelle, but also pointed out the risks that at times can occur with sex work. She said:

There are good days and bad days, some days you make a lot of money, the clients are alright, and its happy days. Bad days can be shit. A bad day could be just because I'm in a bad mood, like if I've had a fight with my boyfriend or something, it's like I just don't want to deal with men [laughs] ... oh other bad days, they can be because you got a bad client or like ... a bad client, maybe they are just rude, or treat you like shit because you're hookin', some can be just rough, others need a bath [laughs] ... girls have died you know [trails off] ... it's rare though like hardly ever happens ... I mean shit can happen to you no matter where you work, right? ... You need to know though I ain't sad. I like that I can make money whenever I need to or want to ... the times I need to is when like my family need money or I have bills to pay ... when I want to well that's when I have my eye on a new dress or some cool shoes ...

It is prudent to recognise that sex work involves both risk as well as pleasure and desire and sits within a broad range of experiences and individual outcomes. Although all three participants discussed that there was risk or danger that can be encountered in the sex industry, all were clear that sex work was their choice, or as Moira said, "it's my choice for now". She also detailed the pleasure that she received from sex work, examples of this include being able to pay her bills, providing for her children, and being able to work school hours. Moira also spoke of how much she enjoyed the way she was able to manipulate clients by capitalising on her sexuality and her looks. She would dress in particular ways and would use her "charms" to entice the clients. She says:

I play the sexy woman, I really make them [the clients] believe I want them, that I am creamin' for them' ... 'Men want to believe we go to this effort for them [laughs] I go to this effort to part them with their cash [laughs] ...

Isabelle made similar comments, including "I loved [sex work], I felt powerful, sexual and in control". Bianca echoed the other participants' positions, saying:

It's all a farce, a big joke. We play with these men, get 'em to want us, dress sexy, laugh at their stupid jokes, pretend to flirt with them, that we want them. I try to do the least amount of work you know ... I don't fuck them much, I get them so turned on that they are quick and it's all over [laughs] ... and I walk away with their money, the jokes on them [laughs].

The above comments by the three participants, Bianca, Moira, and Isabelle, are illustrative of the way in which all three have capitalised on their pussy power. Pussy power is not a reduction of women to their "parts", it is not about genitals. Pussy power as applied in this case study is the honing of gender and sexuality, and its expressions, to entice, in this instance, men; using the magnetism and mystique of their gender and sexuality to control, entice, exploit, and manipulate. In turn, we witness the Indigenous women in Nice Coloured Girls leveraging their female sexuality or pussy power to unshackle themselves from their colonial sexual abjection. Moreover, we witness the unleashing of their agency and power to bring about the exploitation, punishment, and ultimate vengeance as they rob the White man of his money at the conclusion of the film. The utilisation of their bodies as assets that are appealing and sexual is a transgression against social and cultural taboos, although 
capitalising on the body in this way is often seen by sex workers as just "another day in the office" (Perkins and Lovejoy 2007). There is often moralisation and stigma attached to the work done by Indigenous sex workers by family, their communities, and broader society (Fredericks 2010). Their fears and concerns of dealing with external views of how they use their bodies and make their money often result in leading clandestine lives. Bianca says:

I have to be real careful who I tell, my family know, and I will work sometimes to get them money you know ... not my whole family, no way. When I go back home it is not discussed, my family keep my secret ... my community don't know. I would be shamed and kicked out ... my kids would get shamed too ...

Moira was also reluctant to share her experiences in sex work:

Nobody can know who I am, I have to keep it quiet. No one knows, everyone thinks I'm a cleaner, I like it like that ... It is only hard when I have to go get check up's and stuff. I have a different Doctor that I go to for that ... no not my regular Doctor, I don't want him to know, God could you imagine ... nah I keep that stuff separate. That way my worlds don't come together. I don't think my family would ever talk to me again ... they would be so shamed.

Both Moira and Bianca's concerns in sharing their work lives is not surprising. In undertaking this research I have had personal experiences where friends have told me quite assuredly that Indigenous people do not do that kind of thing. It was a moral and cultural assumption that this was not the sort of work that Indigenous people would even consider. Isabelle articulated where she believed the issue to stem from; she stated:

... there's always this idea that people want to moralise you for using your pussy or your mouth to make money ... I think people get very hung up on the sex bit ... I think it comes from society ... probably the church.

It appears that Bianca, Moira, and Isabelle face difficulties that are often bounded by "outsiders" to the sex industry rather than those directly connected with it. Broader societal beliefs around sex work have permeated Indigenous communities reinforcing normative and mostly Western colonio-centric moral ideologies. Indigenous Australian community values are therefore bounded by Christianity, cultural dogma, heteronormativity, community, and family, as well as representations in media and broader society of the deviancy and immorality of sex workers, which tends to draw anxieties and moralisation of sex work within Indigenous communities. This can result in the rejection and exclusion of Indigenous sex workers from their communities under the guise of "community protection" which further serves to misrepresent and alienate Indigenous sex workers, leaving them silenced and marginalised within, and outside, their own communities (Sullivan 2020a). Despite this added complexity, all three maintained their desire to continue working. Moira stated:

I am not going to have someone tell me what I can and can't do with my body ... sure yeah I keep it a secret, but that's because its none of their business, what I do in my time its mine, it's my business. I am not hurting anyone [laughs] well not unless they pay more.

Isabelle said:

Fuck them, fuck them you know. Who are they to tell me what to do with my Black ass. Fuck 'em, they all just jealous, I pay my bills, I look good ... those men at home are never going to look after me the way I can look after myself.

Bianca said:

Home is a funny thing you know, they love me, I know they do. But they don't see all of me. They see only a particular version of me. I am a good girl at home, but it's not who I really am ... I can get racy and wild, but that is not who anyone is gonna marry, you know. But I don't really want that, but my family will never understand that ... my grandparents will never understand ... maybe when they gone... maybe 
Viewing Indigenous women as active agents in a broader context of sex work and through the lens of Nice Coloured Girls captures the multiple subjectivities and the range of experiences, contradictions, and complexities of identity, femininity, and sexuality. They are all agentic, powerful, and fully aware of the manner in which they are utilising their sexualities to manipulate the clients they encounter in their work spaces. The activation of their pussy power by using their bodies as an instrument of their femininity and sexuality illustrates a resurgence of the ways in which agency and sexual empowerment for Indigenous women might be understood, and dare I say, celebrated.

\section{Conclusions}

This article in part addresses the significant gap in the research literature on Indigenous sex workers, as well as Indigenous Australian perspectives of sexuality and gender, by providing counter-narratives to colonio-centric heteronormative perspectives that have been applied in past research with Indigenous peoples. This case study juxtaposed real life sexual situation through the voices of the participants and mediated fictional portrayals of intimacy through the historical-colonial example of Nice Coloured Girls to focus on individual and collective ideologies of sexuality, femininity, and power. These examples are embodied forms of resistance and survival against social, cultural, and political ideologies of Indigenous women that have permeated our communities and broader society, shifting the understanding of Indigenous people in the sex industry away from exploited victims.

Bringing visibility to experiences of Indigenous women works to challenge cultural norms and taboos of our sexual behaviours and gender roles, making it possible to (re)imagine Indigenous women's identities, femininities, and sexualities as a source of strength and independence. A move towards sex-positive ideologies in cultural/social/political spheres can promote bodily autonomy and agency, as well as awareness and celebration of sexual and gender expression. This article is underlined with a refusal to signify powerlessness, victimhood, or exploitation of Indigenous bodies, sexualities, or genders. This right of refusal speaks to my expression of agency as an Indigenous person, as an Indigenous researcher, and as an act of resistance against ongoing colonio-centric violence levelled against Indigenous peoples and our bodies.

Funding: This research received no external funding.

Institutional Review Board Statement: The study was conducted according to the guidelines of the Australian Institute of Aboriginal and Torres Strait Islander Studies Guidelines for Ethical Research and approved by the Human Research Ethics Committee, Macquarie University on 3 October 2013, reference code 5201300644 .

Informed Consent Statement: Informed consent was obtained from all subjects involved in the study. Participants could withdraw their consent at any time.

Data Availability Statement: Not applicable.

Conflicts of Interest: The author declares no conflict of interest.

\section{References}

Bell, Diane. 2002. Daughters of the Dreaming. Melbourne: Spinifex Press.

Bodkin-Andrews, Gawaian, and Bronwyn Carlson. 2016. The legacy of racism and Indigenous Australian identity within education. Race Ethnicity and Education 19: 784-807. [CrossRef]

Bradley, William. 1802. A Voyage to New South Wales, December 1786-May 1792. In First Fleet Collection of Journals, Correspondence and Drawings, ca 1786-1802, Held in the Mitchell and Dixson Libraries. Edited by State Library of New South Wales Mitchell Library. Sydney: Mitchell Library, State Library of New South Wales.

Fredericks, Bronwyn. 2010. Reempowering Ourselves: Australian Aboriginal Women. Signs: Journal of Women in Culture and Society 35: 546-50. [CrossRef]

Franklin, Corrinne. 2014. Belonging to Bad: Ambiguity, Parramatta Girls and the Parramatta Girls Home. Geographical Research 52: 157-67. [CrossRef]

Hooks, Bell. 1992. Selling Hot Pussy: Black Female Sexuality in the Cultural Marketplace. In Black Looks: Race and Representation. London: Turnaround, pp. 61-78. 
Huggins, Jackie. 1995. White Aprons, Black Hands: Aboriginal Women Domestic Servants in Queensland. Labour History 69: 188-95. [CrossRef]

Huggins, Jackie, and Jane Jacobs. 2000. Kooramindandjie Place. In Placebound: Australian Feminist Geographies. Edited by Louise Johnson. South Melbourne: Oxford University Press, pp. 167-81.

Jackson, Crystal A. 2011. Revealing Contemporary Constructions of Femininity: Expression and Sexuality in Strip Club Legislation. Sexualities 14: 354-69. [CrossRef]

Jeffreys, Sheila. 2009. The Industrial Vagina: The Political Economy of the Global Sex Trade. Falmer: Routledge.

Maginn, Paul J., and Christine Steinmetz. 2015. Introduction. In (Sub)urban Sexscapes: Geographies and Regulation of the Sex Industry. Edited by Paul J. Maginn and Christine Steinmetz. London: Routledge, pp. 1-16.

Mavin, Sharon, and Gina Grandy. 2013. Doing Gender Well and Differently in Dirt Work: The Case of Exotic Dancing. Gender, Work E Organization 20: 232-51.

Moffatt, Tracey. 1987. Nice Coloured Girls. San Francisco: Kanopy Films Australia.

Moreton-Robinson, Aileen. 2000. Talkin' Up to the White Woman: Indigenous Women and Feminism. Brisbane: University of Queensland Press.

O'Sullivan, Sandy. 2019. A lived experience of Aboriginal Knowledges and perspectives: How cultural wisdom saved my life. In Practice Wisdom: Values and Interpretations. Edited by Joy Higgs. Leiden: Brill, pp. 107-12.

Perkins, Roberta, and Frances Lovejoy. 2007. Call Girls: Private Sex Workers in Australia. Sydney: UNSW Press.

Read, Kate W. 2013. Queering the Brothel: Identity Construction and Performance in Carson City, Nevada. Sexualities 16: 467-86. [CrossRef]

Roach, Shoniqua. 2018. Black pussy power: Performing acts of black eroticism in Pam Grier's Blaxploitation films. Feminist Theory 19: 7-22. [CrossRef]

Sanders, Teela, Maggie O'Neill, and Jane Pitcher. 2017. Prostitution: Sex Work, Policy E Politics. London: Sage.

Showden, Carisa R. 2012. Theorising Maybe: A Feminist/Queer Theory Convergence. Feminist Theory 13: 3-25. [CrossRef]

Spillers, Hortense. 2000. Mama's baby, papa's maybe: An American grammar book. In African American Literary Theory: A Reader. Edited by Winston Napier. New York: New York University Press, pp. 257-79.

Sullivan, Corrinne Tayce. 2017. Aboriginal inmate experiences of Parramatta girls home. Australian Aboriginal Studies 2: 84-97.

Sullivan, Corrinne Tayce. 2018. Indigenous Australian women's colonial sexual intimacies: Positioning indigenous women's agency. Culture, Health \& Sexuality 20: 397-410.

Sullivan, Corrinne Tayce. 2020a. Who holds the key? Negotiating gatekeepers, community politics and the 'right' to research in Indigenous spaces. Geographical Research 58: 344-54. [CrossRef]

Sullivan, Corrinne Tayce. 2020b. Indigenous Australian Experiences of Sex Work: Stories of Agency, Autonomy and Self-Determination. Sydney: Macquarie University.

Sullivan, Corrinne Tayce, and Madi Day. 2019. Indigenous transmasculine Australians \& sex work. Emotion, Space and Society 32: 100591. [CrossRef]

Vercoe, Caroline. 1997. Not So Nice Colored Girls: A View of Tracey Moffatt's Nice Coloured Girls. Pacific Studies 20: 151-59.

Weitzer, Ronald. 2012. Legalizing Prostitution: From Illicit Vice to Lawful Business. New York: NYU Press. 